\title{
Bioproduction and extraction of jasmonates
}

\author{
Laís Baichi Buttarello ${ }^{1 *}$, Alexandre Zanelli dos Santos ${ }^{2}$, Murilo Daniel de Mello Innocentini ${ }^{1}$, \\ Miriam Verginia Lourenço ${ }^{2}$ \\ From 5th Congress of the Brazilian Biotechnology Society (SBBIOTEC) \\ Florianópolis, Brazil. 10-14 November 2013
}

\begin{abstract}
Introduction
Jasmonates are a growing class of compounds of vegetable origin which present phytoregulator activity and toxicity against some types of cancer cells. Additionally the jasmonates have also shown activity against some types of nematodes [1]. Jasmonates available on the market are of plant origin or synthetic, present costs are still high. Like plants, some microorganisms have the potential to produce jasmonates. Some microorganisms have the potential to produce this class of compounds, including filamentous fungus Botryosphaeria rhodina has shown to be the most promising. The choice of the strain and optimization of process steps are fundamental premises for increasing the scale of production [2]. Furthermore, the optimization of the steps of extraction and purification of the product in the fermentation broth are essential to ensure the viability of the process. Currently, studies of recovery of jasmonates produced by Botryosphaeria rhodina are based on organic solvents. In this work, an alternative recovery route is proposed, based on adsorption, and the determination of the adsorption kinetics of jasmonates present in fermented using ion exchange resins Amberlite ${ }^{\circledR}$ is presented.
\end{abstract}

\section{Methodology}

Fermentations were conducted in Erlenmeyer of $250 \mathrm{~mL}$ using $50 \mathrm{~mL}$ of culture medium $\mathrm{M} 2$ and $5 \mathrm{~mL}$ of inoculum. After a period of fermentation, the mycelium was removed by vacuum filtration and subjected to fermentation extraction tests. To do this the filtrate collected was adjusted to $\mathrm{pH}$ 3.0. Then it was mixed in an Erlenmeyer of $100 \mathrm{~mL}$ of fermented and $1 \mathrm{~g}$ of resins Amberlite ${ }^{\mathbb{B}}$ XAD-2, XAD-4 or XAD-7 separately, put under stirring at 130 rpm for 60 minutes [3]. Samples $(5 \mathrm{~mL})$ were collected after $2,4,6,8,10,20,40$ and 60 minutes of contact and subsequently subjected to extraction in order to determine

\footnotetext{
${ }^{1}$ Chemical Engineering Course, UNAERP, University of Ribeirao Preto, SP, Brazil

Full list of author information is available at the end of the article
}

the content of jasmonates remaining in each sample. The extractions were performed by liquid-liquid partition using ethyl acetate as solvent extractor. The monitoring was performed by CCDC (Thin Layer Chromatography Comparative) using silica chromatoplates with UV indicator. The quantification of jasmonates was performed by HPLC (High Performance Liquid Chromatography) using a chromatograph SHIMADZU (LC-10AD VP) coupled to a detector of diode array. It was used a $\mathrm{m}$ ) and a solvent system $\mu$ Supelcosil C18 column $(25 \mathrm{~cm} \times 4.6 \mathrm{~mm}$ id, 5 comprised of $\mathrm{MeOH}$ :acetic acid 0.1\% (60:40). The solvent flow was $0.85 \mathrm{~mL}$.min- 1 with analysis monitored at $210 \mathrm{~nm}$. For quantification it was used the external standard method, by plotting a calibration curve with standard solutions of pure $\mathrm{AJ}$ at concentrations ranging from 0.1 - $1.0 \mathrm{mg} \cdot \mathrm{mL}-1$.

\section{Results and conclusions}

The results showed that the efficiency of XAD- 2 resin was $84.02 \%$, XAD- 4 was $96.3 \%$ and XAD-7 $95.15 \%$. With the data analyzed, it was concluded that even though the Amberlite XAD-4 has a slightly higher efficiency in the time of equilibrium, the resin XAD-7 after 40 minutes showed higher adsorption (93.01\%) over XAD-4 (85.19\%). Therefore, for the continuation of studies, the Amberlitess ${ }^{\circledR}$ XAD-7 will be used.

\begin{abstract}
Acknowledgements
FAPESP, CNPq, UNAERP

Authors' details

${ }^{1}$ Chemical Engineering Course, UNAERP, University of Ribeirao Preto, SP Brazil. 'Biotechnology Unit, UNAERP, University of Ribeirao Preto, SP, Brazil.
\end{abstract}

Published: 1 October 2014

\section{References \\ 1. Gavin AS, Faggion SA, Hernandes C, Lourenço MV, França SC, Beleboni RO: Nematocidal esffects of natural phytoregulators jasmonic acid and methyl-jasmonate against Pratylenchus zeae and Helicotylenchus spp. Natural Product Research 2012, 26:1-8, Doi:10.1080/14786419.2012.686910.}


2. Posch $A E$, Herwing $C$, Spadiut O: Science-based bioprocess design for filamentous fungi. Trends in Biotechnology 2013, 31(1):37-44, Doi:10.1016/j. tibtech.2012.10.008.

3. Barros ANC: Purificação de penicilina $\mathrm{G}$ por adsorção em resinas hidrofóbicas. Dissertação Mestrado (Universidade Federal de São Carlos); 2008, 80f.

doi:10.1186/1753-6561-8-S4-P201

Cite this article as: Buttarello et al:: Bioproduction and extraction of jasmonates. BMC Proceedings 2014 8(Suppl 4):P201.

Submit your next manuscript to BioMed Central and take full advantage of:

- Convenient online submission

- Thorough peer review

- No space constraints or color figure charges

- Immediate publication on acceptance

- Inclusion in PubMed, CAS, Scopus and Google Scholar

- Research which is freely available for redistribution

Submit your manuscript at www.biomedcentral.com/submit
C Biomed Central 